\title{
Canadian Tree Farms
}

\author{
By C. STUART FRANCIS, Torch River, Sask. \\ (Member of the Canadian National Tree Farm Committee)
}

A development known as Canadian Tree Farms was launched in May of 1953, with the objective of improving the protection and also the management of millions of acres of privately owned forest land all across Canada.

This activity is sponsored nationally by the Tree Farm Committee of the Canadian Forestry Association and it is modelled after a similar project which has been in operation since 1942 in the United States, where over 27 million acres of land are now certified as Tree Farms.

Canadian Tree Farms are privately owned forest lands which are to be devoted to continuous production of wood crops. Tree Farms are certified by trained foresters representing the local Tree Farm Committee of the Canadian Forestry Association after the owner of the land has agreed to the following commitments:

1. Maintain the land for growing continuous tree crops.

2. Protect the land adequately.

3. Adopt cutting practises which will ensure future forest crops.

4. Allow the Committee's foresters to inspect the tree farm.

More detailed objectives of the Canadian tree farm system are, of course, to foster public interest by farmers and forest land owners in the possibilities of greater productivity and higher incomes from forest lands on the farms, and to endeavor to get better management of those forest lands by practicing selective cutting, tree release work, reforestation by better quality and more valuable species and by better utilization by using the various parts of a tree for different wood products for which the various parts of a tree are best suited, such as for lumber, pulpwood, cordwood, etc., also improving the woodlot by keeping livestock out of valuable stands of trees, and to protect these woodlots or forest areas from fire by clearing fire guards and by strategic roads throughout the area which would help in forest fire control and in tree extraction, also to keep down insect damage as far as possible.

By managing forest lands in a practical and systematic manner we are also helping to keep the whole country in a more natural balance. To do this it is estimated that $20 \%$ of the land area should be maintained in tree growth in order to keep down evaporation, wind damage, and to control fluoding and erosion. A district dotted with bluffs and windbreaks is much more attractive to look at and a let more comfortable to live in at all seasons of the year. Therefore, even if we receive the benefits from a well managed tree farm, that I have just outlined, I am sure the effort js well worthwhile. But I am sure there are many other benefits to be derived as well. Not the least is the aesthetic value of such a worthwhile program. There should be more objectives aimed at in farm living than just farming for profit only. We should remind ourselves that each generation has a duty and responsibility to each succeeding generation in keeping all the resources of our country in a stable and productive condition at all times.

Mr. E. J. Marshall, Saskatchewan's director of forests, pointed out recently one other important benefit from owning a farm woodlot. He believes that a woodlot owner with a fair sized woodlot, say from 20 acres up, may consider it in the same catagory as an insurance policy, for, as more wood is grown than is needed on the farm, this surplus may be drawn on when there is a decline or failure of other farm crops to pay current accounts, to construct new buildings, or to produce additional property or equipment.

Now I think that is all I need say in regard to the benefits that can be derived from an extensive Canadian Tree Farm system, except possibly to mention the fact that tree farm- 
ing must be considered as a distinctly long-term project and therefore must be approached with a long-term viewpoint. Working in the woods is a change from working in the open fields or farm yard, for it offers the nearest thing we have to primeval conditions and completes the picture of a well balanced farm which gives those human satisfactions that we call a way of life to men and women who enjoy country living.

\section{Nature's Simple Pleasures}

\section{By Mrs. Hilda Newton \\ Lake Marguerite, Indian Head}

In early summer we found, when wiring the home for electricity, a family of bats who were quite comfortable "hanging" around the brick chimney in the attic, keeping warm during the damp chilly days of May and June. As soon as the sun popped from sight, out they would come, squeaking like tiny mice, busily searching around eaves and windows for flies and moths. We found very few of those large Blue Bottles - Nature's strange creatures are here for a purpose, so the family were not disturbed.

The cold wet summer must have been hard on the young birds. We did not see many Meadowlarks or Bluebirds this year - only one flock of about twenty Bluebirds during the last week of September. Song Sparrows and Grasshopper Sparrows were very plentiful. We did miss the rollicking song of our Western Meadowlark, who by the way, can out-do his Eastern cousins in gayety. I was sure Ontario didn't have any until, one day, hearing the strange song, I hurried out to see - a meadowlark! He w a s familiar in size and dress, but the song, though not unmusical, wasn't nearly so merry.

How many, like myself, thought our Prairie Lily was a native of our western provinces only? When going east by train in early July, I was delighted to see so many along the line, until just past Bran- don. Then again, after Fort William, on along the shore of Lake Superior were red patches, some bravely nodding to us from the bare rocks. One wonders where they could find sufficient food.

There were also dwarf bushes of deep red roses, covered with blooms. Further on these were replaced by dainty clusters of Blue Iris, reflected in the tiny pools. Moutain Ash were white with bloom and peeping from under the evergreens were hundreds of tiny flowers, perhaps Hapaticas. Very late, we thought, but snow stays late in the deep woods.

\section{Bird Migration Study}

Mrs. C. E. Boon, Tullis, Sask.

I note you were disappointed that the Migration Study covered only the eastern half of the province. The simple reason for that may be that we, in the western half, just don't see many of these birds.

This is the typical bald prairie. The only trees anywhere close are man-planted. I have no doubt that many, or all, of the birds pass through, but they waste no time about it. If one happens to be out when they are going through, you see them - if not, you don't. I suppose the solution is to spend more time in the field, but that's not always easy.

I started to keep a record and ended up with only eight, out of twentynine. Only once have I seen a spring migration of warblers. That was in May, 1950. It was cold and windy and they were in hundreds among the bushes in the coulee. That was in the evening. Next morning they were gone. They were Yellow and Myrtle Warblers. There are ten birds on that list I have never seen here at all.

I have had reports of two Whooping Cranes among the Sandhill Cranes on the river. I haven't seen them myself, and with everyone seeing Whooping Cranes in anything white (which is a good thing) one is apt to be rather sceptical. We saw one several times with the Sandhill Cranes in 1949. Once seen, there is no mistaking them. 